\title{
UŽDELSTO MELANOMOS CHIRURGINIO GYDYMO PAVOJAI COVID-19 PANDEMIJOS METU. KLINIKINIS ATVEJIS
}

\author{
Milda Valatkevičiūtė ${ }^{1}$, Mindaugas Kazanavčius ${ }^{2}$, Adas Čepas ${ }^{2}$ \\ ${ }^{1}$ Lietuvos sveikatos moksly universiteto Medicinos akademija, Medicinos fakultetas, \\ ${ }^{2}$ Lietuvos sveikatos mokslu universiteto ligoniness \\ Kauno kliniku Plastinès ir rekonstrukcinès chirurgijos klinika
}

Raktažodžiai: melanoma, chirurgija, COVID-19.

\section{Santrauka}

COVID-19 pandemija paveikè daugelio ligų, įskaitant ir melanomą, gydymą bei diagnostiką. Šis klinikinis atvejis parodo, kaip pandemija veikia paciento, nesergančio SARS-CoV-2 viruso infekcija, chirurginio gydymo eigą. Pristatome $83 \mathrm{~m}$. moters, kuri kreipèsi dèl greitai didèjančio darinio kairiojo dilbio odoje, klinikinị atvejị. Darinio didejimas pastebètas $2020 \mathrm{~m}$. sausio mèn., tačiau dèl kovo mén. pasikeitusios epidemiologinés situacijos paciente delsė kreiptis ị gydymo įstaigą. Pacientei bendrinèje nejautroje $2 \mathrm{~cm}$ vizualiai sveikų audinių ribose atlikta auglio ekscizija. Susidaręs minkštụjų audinių defektas autodermoplastikos metodu padengtas viso odos storio transplantantu, paimtu nuo kairiojo žasto vidinio paviršiaus. Gama zondu identifikuotas ir pašalintas radioizotopu pažymètas pažastinis limfmazgis. Dèl per šią krizę laiku negydytos melanomos gali padidèti mirtingumas, sergamumas ir sveikatos priežiūros išlaidos.

\section{Ivadas}

COVID-19 pandemija paveikè daugelio ligų, įskaitant ir melanomą, gydymą bei diagnostiką. Pastebimos dvi pagrindinès uždelsto gydymo ir diagnostikos priežastys: pacientu baimè susirgti SARS-CoV-2 viruso sukelta infekcija ir sudètingas gydytojų specialistų prieinamumas dẻl vykdomų nuotolinių konsultacijų. Melanoma tai - agresyviausias piktybinis odos epidermio melanocitų navikas. Melanoma linkusi greitai metastazuoti ị sritinius limfmazgius ir vidaus organus. Laiku nepradejjus gydymo, dažna letali baigtis [1]. Nacionalinio vėžio instituto duomenimis, Lietuvoje kasmet nustatoma maždaug 320 naujų susirgimų melanoma, iš kurių du trečdaliai tenka moterims ir vienas trečdalis vyrams. Mazginė melanoma yra antra pagal dažnumą - 15-30 proc. visų melanomos atvejų [2]. Šiuo klinikiniu atveju norime pademonstruoti, kaip pandemija veikia paciento, nesergančio SARS-CoV-2 viruso infekcija, chirurginio gydymo eigą.

Tyrimo tikslas - aprašyti neịprastą melanomos ligos eigą ir apžvelgti naujausią literatūrą, aprašančią gydymo sunkumus, atidèliojant chirurgini gydymą dèl COVID-19 pandemijos.

\section{Klinikinis atvejis}

83 metų moteris apie 13 metų jautè didejjantị darini kairiojo dilbio odoje. Darinio didejimas pastebètas 2020 $\mathrm{m}$. sausio mèn., tačiau dèl kovo mènesi pasikeitusios epidemiologinès situacijos paciente delsè kreiptis ị gydymo ìstaigą. Iš anamnezès žinoma, kad pacientè serga difuzine didelių ląstelių limfoma (taikoma chemoterapija). Apžiūros metu kairiojo dilbio odoje nustatytas $7 \times 6 \times 4,5 \mathrm{~cm}$ juodos

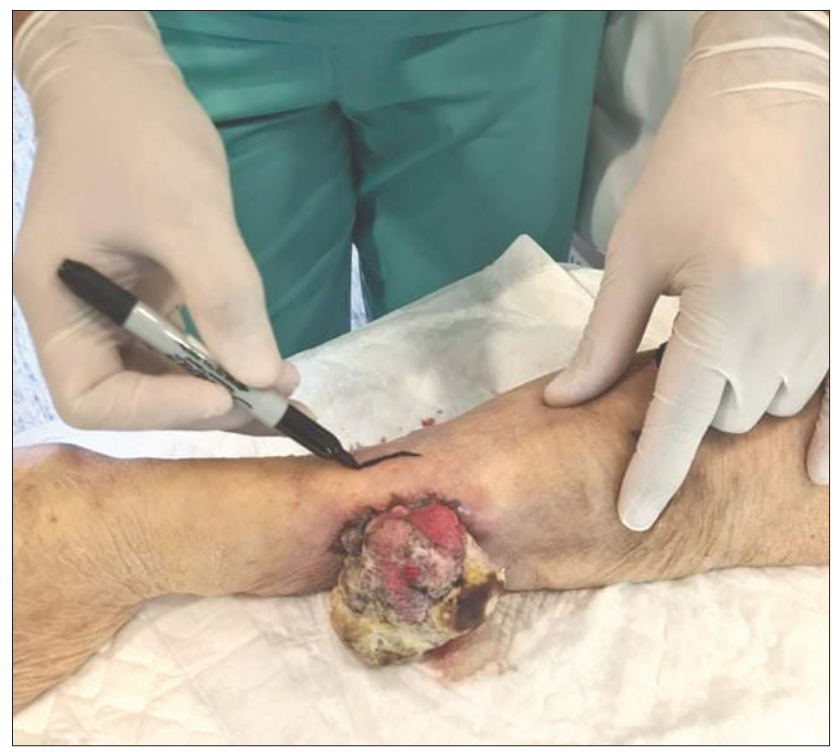

1 pav. Išopejęes, šlapiuojantis, kraujuojantis $7 \times 6 \times 4,5 \mathrm{~cm}$ mazgas kairiojo dilbio odoje 
spalvos išopėjęs, iš odos iškilęs, šlapiuojantis, kraujuojantis mazgas (1 pav.). Medicininès dokumentacijos duomenimis, darinio dydis per vieną mènesi pakito apie 1 centimetrą. Staigų darinio didèjimą galejjo lemti pacientès gretutinè liga ir jos sukelta imunosupresinè būklè. Operacinis gydymas paskirtas $2020 \mathrm{~m}$. spalio 28 dieną, tačiau atidètas dèl susiklosčiusios epidemiologinès situacijos, šalyje paskelbto karantino ir apriboto judejjimo. Pakartotinai operacija suplanuota $2020 \mathrm{~m}$. lapkričio mènesị, tačiau pacientei teko izoliuotis dèl kontakto su sergančiuoju COVID-19. Trečią kartą operacija paskirta $2020 \mathrm{~m}$. gruodžio 17 dieną. Paciente atvyko ị LSMUL Kauno klinikų Plastinès ir rekonstrukcinės chirurgijos kliniką planinei naviko ekscizijai su sarginio limfmazgio biospija (SLB). Pacientei bendrineje nejautroje $2 \mathrm{~cm}$ vizualiai sveikų audinių ribose atlikta auglio ekscizija. Susidaręs minkštujų audinių defektas padengtas atliekant autodermoplastiką viso odos storio transplantantu, paimtu nuo kairiojo žasto vidinio paviršiaus. Gama zondu identifikuotas ir pašalintas radioizotopu pažymètas pažastinis limfmazgis. Tai standartinis sergančiujų melanoma gydymo metodas, esant didelei regioninių limfmazgių metastazių rizikai. Šio metodo taikymas suteikia svarbios prognostinès informacijos ir leidžia identifikuoti pacientus, kurių sarginis limfmazgis yra patologinis ir kuriems reikalinga adjuvantinè terapija [3]. Sergančiujų melanoma, kurios storis $>3,50$ $\mathrm{mm}, 10$ metų išgyvenamumas buvo žymiai blogesnis, kai SLB buvo teigiama, palyginti su tais, kurių SLB buvo neigiama (48,0, palyginti su 64,6 proc., ŠS $1,75,95 \%$ PI 1,07 $-2,87$ ) [4]. Atlikta neskaitmeninè dermatoskopija parode tipini melanomos vaizdą: aprašomos pseudopodijos, nehomogeniškumas, netaisyklingas pigmentinis tinklelis. Atlikta operacinès medžiagos biopsija ir histopatologinis tyrimas. Diagnozuota odos mazginè melanoma, pT4b N2c(sn) R0. Navikinèse ląstelèse aktyvuojančios BRAF V600 mutacijos nerasta, todèl adjuvantinè terapija neskiriama.

\section{Gydymo rezultatai}

Po atliktos operacijos pacientei komplikacijų nebuvo, tačiau literatūroje aprašomos galimos dažniausios komplikacijos, susijusios su chirurgine ekscizija, yra žaizdos infekcija (7,7 proc.) arba seroma (6,4 proc.) [5]. E. Lindqvist ir kt. (2019) atliktame tyrime nustatyta, kad po sarginio limfmazgio biopsijos komplikacijos pasireiškia 12,3 proc. pacientų [5].

\section{Diskusija}

Duomenų apie COVID-19 poveikị melanomos eigai ir gydymui yra nedaug [6]. Ö. Elmas ir kt. (2020) nustaté, kad T3 ar T4 stadijos melanomų chirurginis gydymas yra prioritetinis, o adjuvantini gydymą galima atidèti iki 12 savaičių [6]. Odos pigmentinių darinių diagnostika ir valdymas pan- demijos metu dažniausiai reikalauja vizito pas dermatovenerologą, o sudètingesni atvejai, kaip ir mūsų aptartas klinikinis atvejis, reikalauja plastinès ir rekonstrukcinès chirurgijos gydytojo kompetencijos.

\section{Išvados}

1. Dèl laiku negydomos melanomos per šią krizę gali padidèti mirtingumas, sergamumas ir sveikatos priežiūros išlaidos [7].

2. Svarbu laiku taikyti chirurginį melanomos gydymą, atidedant ji ne vèliau kaip 3 mèn. nuo diagnozès nustatymo [6].

3. Dèl pacientų baimès kreiptis ị gydymo įstaigą, pandemijos metu blogèja gydymo rezultatai [6].

\section{Literatūra}

1. Aukštakojytė Ž., Pociūtė A., Trinkūnienė V. Melanoma: rizikos veiksniai ir prevencinès priemonès. Sveikatos mokslai, 2020;30(4):81-85.

https://doi.org/10.35988/sm-hs.2020.101

2. Hassel JC, Enk AH. Melanoma. In: Fitzpatrick's Dermatology, 9th Edition, Kang S, Amagai M, Bruckner AL, et al (Eds), McGraw-Hill Education, 2019;1:1982.

3. Voit CA, van Akkooi AC, Schäfer-Hesterberg G, et al. Rotterdam criteria for sentinel node (SN) tumor burden and the accuracy of ultrasound (US)-guided fine-needle aspiration cytology (FNAC): can US-guided FNAC replace SN staging in patients with melanoma? J Clin Oncol 2009;27:4994.

https://doi.org/10.1200/JCO.2008.19.0033

4. Stone MD, et al. Evaluation and treatment of regional lymph nodes in melanoma. https://www.uptodate.com/contents/evaluation-and-treatment-of-regional-lymph-nodes-in-melanoma

5. Lindqvist EK, Laine E, Kamali A, Sars C, Gillgren P, Schultz I. Risk factors for post-operative complications after sentinel lymph node biopsy for cutaneous melanoma: results from a large cohort study. J Plast Reconstr Aesthet Surg. 2019;72(12):1956-1962.

https://doi.org/10.1016/j.bjps.2019.08.011

6. Elmas ÖF, Demirbaş A, Düzayak S, Atasoy M, Türsen Ü, Lotti T. Melanoma and COVID-19: a narrative review focused on treatment. Dermatologic Therapy 2020; 33:e14101.

https://doi.org/10.1111/dth.14101

7. Gomolin T, Cline A, Handler MZ. The danger of neglecting melanoma during the COVID-19 pandemic. J Dermatolog Treat 2020;31(5):444-445.

https://doi.org/10.1080/09546634.2020.1762844

RISKS OF DELAYED MELANOMA SURGICAL TREATMENT DURING THE COVID-19 PANDEMIC. CASE REPORT

M. Valatkevičiūtè, M. Kazanavčius, A. Čepas

Keywords: melanoma, surgery, COVID-19. 


\section{4}

\section{Summary}

The COVID-19 pandemic has affected diagnosis and surgical treatment of many diseases, including melanoma. We want to demonstrate this case report that pandemic itself affects patient's surgical treatment even without being ill with the actual SARS-CoV-2 virus infection. We present an 83-year-old female who complains with rapidly increasing formation in the skin of the left forearm. The increase was first observed in 2020 January, but due to changes in the epidemiological situation since March the patient delayed seeking medical attention. The patient underwent tumor excision within $2 \mathrm{~cm}$ of visually healthy tissue under general anaesthesia.
The resulting soft tissue defect was covered by autodermoplasty with a full-thickness skin graft taken from the inner surface of the left arm. A radiolabeled axillary lymph node was identified and removed. Untreated melanoma can increase mortality, morbidity and health care costs during this COVID-19 crisis.

Correspondence to: milda.valatkeviciute@gmail.com

Gauta 2021-03-04 